\title{
Heritability of the Resistance to Potato Leafhopper in Dry Bean
}

\author{
J.W. Gonzales ${ }^{1}$ and D.P. Coyne ${ }^{2}$ \\ Department of Agronomy and Horticulture, University of Nebraska, Lincoln, \\ NE 68583
}

\author{
D.T. Lindgren ${ }^{3}$ and D. Schaaf \\ West Central Research and Extension Center, University of Nebraska, 461 \\ West University Drive, North Platte, NE 69101
}

\author{
K. M. Eskridge \\ Department of Biometry, University of Nebraska, Lincoln, 68583
}

Additional index words. Empoasca fabae, Empoasca kraemeri, Phaseolus vulgaris L., regression analysis, plant breeding

\begin{abstract}
The potato leafhopper (PLH), Empoasca fabae Harris is the most important Empoasca species attacking dry beans (Phaseolus vulgaris L.) in North America. The objective of this study was to determine the heritability $\left(h^{2}\right)$ of PLH injury based on parent-offspring regression analysis of $F_{3}$ means on individual $F_{2}$ plants derived from crosses of pinto 'Sierra' (resistant) x great northern 'Starlight' (susceptible), and black bean 'Tacarigua' (resistant) $x$ 'Starlight' (susceptible). Low narrow-sense heritability values of $0.29 \pm 0.06$ and $0.28 \pm 0.10$, respectively, were obtained for the above crosses. The low narrow-sense heritability estimates indicated large environmental effects on the expression of PLH injury in dry beans. An allelic test showed that both resistant parents possessed the same genes for resistance.
\end{abstract}

Dry edible beans (Phaseolus vulgaris L.) are an important cash crop in North America, and a staple in Latin America and in east African countries (Singh, 1999). Potato leafhopper (PLH), Empoasca fabae Harris, is an insect pest attacking dry beans in some regions of North America, including both the U.S. and Canada (Murray et al., 2000; Schaafsma et al., 1998). The related species, E. kraemeri Ross and Moore, is the primary leafhopper species of dry beans in Latin America (Kornegay and Cardona, 1990). Yield losses of about $20 \%$ caused by E. fabae were reported on susceptible bean cultivars at North Platte, Nebr. (Lindgren and Coyne, 1995), while yield losses up to $64 \%$ caused by E. kraemeri were reported in Latin America bean studies (van Schoonhoven et al., 1985).

Symptoms of PLH injury may include leaf yellowing and distortion, downward curling of the leaves, necrosis at the leaf tips and leaf margins (hopperburn), and stunting of plants (Kornegay et al., 1986). These injuries may be

Received for publication 12 Mar. 2004. Accepted for publication 17 Mar. 2004. Nebraska Agricultural Research Division journal number 13736. Research was conducted under Projects Nos. 20-036 and 20042. We acknowledge financial support from the Title XII Bean/Cowpea CRSP (AID contract DNA-13106-55-6008-00), the Nebraska Dry Bean Commission, and the Nebraska Dry Bean Growers Association. We appreciate the assistance of technicians James Reiser, Lisa Sutton, and graduate student Nedim Mutlu, University of Nebraska-Lincoln.

${ }^{1}$ Current address of senior author: Fundación 'PROINPA', Av. Blanco Galindo km. 12.5, Casilla 4285, Cochabamba (Bolivia).

${ }^{2}$ Deceased.

${ }^{3}$ Corresponding author. caused by both nymphs and adults feeding on the plants (Kornegay et al., 1986).

Application of systemic and foliar spray insecticides is a common method to control leafhoppers on dry beans (Gonzalez and Wyman, 1991), but tolerance and antixenosis have been demonstrated to be important mechanisms of resistance to leafhopper feeding on dry beans (Kornegay et al., 1986; Kornegay and Temple, 1986). Breeding dry beans for resistance to PLH injury could be a cost effective alternative to the use of systemic and foliar spray insecticides to control this pest. Resistance is regarded as being less damaging to the environment when compared to the use of insecticides to control leafhopper feeding. Lindgren and Coyne (1995) showed significant differences among cultivars in response to PLH feeding based on symptoms of plant injury and on seed yield. Selected dry bean breeding lines developed by the Centro Internacional de Agricultura Tropical (CIAT) for tolerance to E. kraemeri showed useful levels of resistance to PLH (E. fabae) injury in Ontaria, Canada, as well (Schaafsma et al., 1998).

Nonadditive inheritance and large environmental effects of E. kraemeri injury on P. vulgaris has been reported (Galwey and Evans, 1982). However, there is only limited information in the literature concerning the inheritance of dry bean resistance to E. fabae. No estimates of heritability of the resistance to E. fabae in dry beans have been previously reported. Knowledge of the inheritance of resistance of dry beans to E. fabae is a requisite in developing effective selection and testing methods for resistance as well as for developing a plant breeding strategy for improving this trait.
The main objective of this research was to determine narrow-sense heritability $\left(\mathrm{h}^{2}\right)$ estimates of leafhopper injury based on the regression of $\mathrm{F}_{3}$ means on $\mathrm{F}_{2}$ plants derived from crosses between resistant and susceptible lines under field conditions.

\section{Materials and Methods}

Crosses were made in the greenhouse between the pinto bean cultivar, 'Sierra' (resistant to PLH injury) $\mathrm{x}$ the great northern bean 'Starlight' (susceptible to PLH injury), and the black bean 'Tacarigua' (resistant to PLH injury) x 'Starlight' (susceptible to PLH injury) to produce segregating populations to study the inheritance and heritability of resistance to E. fabae injury in dry beans. These parents were selected based on the reaction of dry bean cultivars to PLH injury in a previous study (Lindgren and Coyne, 1995).

Parents, $F_{1}$, and $F_{2}$ progenies $\left(160 \mathrm{~F}_{2}\right.$ individuals per cross) from the two crosses were planted in two, one and four-row plots, respectively, in the field at the University of Nebraska West Central Research and Extension Center (WCREC), North Platte, on 27 May 1999. The rows were planted $0.9 \mathrm{~m}$ apart and within row spacing was $15 \mathrm{~cm}$ in all experiments. Parents and $47 \mathrm{~F}_{3}$ families, with each family consisting of $20 \mathrm{~F}_{3}$ plants per row in each replication were planted for two crosses at two different sites in the field on 25 to 26 May 2000 at WCREC. The $\mathrm{F}_{3}$ families were derived from random $\mathrm{F}_{2}$ plants in each cross. The $\mathrm{F}_{3}$ families and parents were planted in rows $3 \mathrm{~m}$ long and $0.9 \mathrm{~m}$ apart and arranged in a $7 \times 7$ incomplete lattice design with two replications in two widely separate fields. One field site had unmowed grass strips near the plots. Grass near the plots seems to be favorable for attracting leafhoppers. There were no extended grass areas near the second field site. A previous study indicated these sites had high potential levels of PLH infestation (Lindgren and Coyne, 1995).

An allelic test was conducted by crossing the resistant parents 'Sierra' and 'Tacarigua'. Seeds of 'Sierra', 'Tacarigua', $43 \mathrm{~F}_{1}$, and 269 $\mathrm{F}_{2}$ were planted in an observation test on 26 May 2000, at the WCREC in rows $3 \mathrm{~m}$ long and $0.9 \mathrm{~m}$ wide. A sprinkler system was used to irrigate the plots as needed to produce good plant growth.

Visual scores of PLH injury were recorded on a single plant basis for parents, $F_{1}$, and $F_{2}$ plants on 8 Aug. 1999, when plants were between developmental stages R6 (flowering) and R7 (pod formation). Developmental stages were defined according to the Centro Internacional de Agricultura Tropical scale (CIAT 1986). PLH injury ratings were recorded for twenty individuals per $\mathrm{F}_{3}$ family on 4 to $6 \mathrm{Aug}$. 2000 (first reading) when plants were at the R6 stage (flowering), and on 16 to 18 Aug 2000 (second reading) at the $\mathrm{R} 7$ (pod formation) stage of development. No differences were observed in ratings between the first and second dates, so the former readings were used for data analysis. The rating scale for leafhopper injury was $1=$ no visible injury; 2 = slight leaf 
yellowing with some leaf curling; $3=$ visible yellowing on leaves, visible leaf curling, and slight leaf wrinkling; $4=$ significant injury with yellowing on most of the leaves, significant leaf curling and significant leaf wrinkling; and $5=$ severe injury, leaves turn from yellow to brown color and/or show severe leaf yellowing and wrinkling.

Statistical analysis was performed using General Linear Model and Mixed procedures of SAS (SAS, 1997). Bean lines were considered fixed effects and sites were considered random effects. Narrow-sense heritability was calculated by regressing $\mathrm{F}_{3}$ family means on individual $\mathrm{F}_{2}$ plant values using the formula: $h^{2}=2 / 3 b \pm$ standard error (Smith and Kinman, 1965).

\section{Results and Discussion}

Although no actual PLH counts were made, a moderate to high natural incidence of leafhopper infestation was observed on susceptible plants in all locations in 1999 and 2000. No differences were noted between years for infestation levels. A differential response to PLH injury was observed between parents for both $\mathrm{F}_{2}$ populations in 1999. 'Sierra' and 'Tacarigua' were resistant while 'Starlight' was susceptible to leafhopper injury in all trials (Fig. 1). $F_{2}$ and PLH injury rating distributions were discrete ( 3 classes), while the number of classes (5) and their distributions on the $\mathrm{F}_{3}$ suggests a quantitative inheritance pattern (Fig. 1). Based on analyses of variance (ANOVA), variances among F3 families were highly significant for both populations. Regression coefficients $(b=$ $0.44 \pm 0.06$ and $0.42 \pm 0.10)$ and correlation ( $r=0.72$ and 0.51 ) were calculated from the $\mathrm{F}_{2}-\mathrm{F}_{3}$ parent-offspring regression analyses for PLH injury for the crosses 'Sierra' $x$ 'Starlight', and 'Tacarigua' $x$ 'Starlight', respectively. Low narrow-sense heritability values of $h^{2}=0.29$ \pm 0.06 and $0.28 \pm 0.10$ were estimated for the crosses 'Sierra' $x$ 'Starlight' and 'Tacarigua' x 'Starlight', respectively.

No segregation for susceptibility to PLH injury was observed in the $\mathrm{F}_{2}$ generation of the crosses of the two resistant parents 'Sierra' and 'Tacarigua' suggesting that they possessed the same genes for resistance (data not shown).

A moderate level of PLH infestation each year contributed to a differentiation between parents and among progenies. In this study, most of the injury ratings ranged from 1 (no apparent injury) to 3 (visible yellowing, curling, and wrinkling on leaves). Only about $3 \%$ to $4 \%$ of the $\mathrm{F}_{3}$ families had a mean score not significantly different from the mean of the resistant parent. Two to three families did not segregate for resistance similar to the resistant parent out of a total of $47 \mathrm{~F}_{3}$ families from each cross. Therefore, the best fit for the data suggests that only a few (probably 3 to 4 ) genes determine resistance to PLH injury in dry beans. The mechanism of resistance in the parents in this study is not known. Extensive studies at the CIAT indicated that tolerance is probably the main mechanism of resistance to leafhopper injury (CIAT, 1980). More than 22,000 common bean accessions were evalu- ated at CIAT for resistance to leafhopper ( $E$. kraemeri) injury, with only $3.4 \%$ of them classified as resistant (Kornegay and Cardona, 1990). Most of the resistant lines showed tolerance to leafhopper damage (Kornegay and Cardona, 1990). Tolerance and antixenosis resistance mechanisms are mentioned most frequently as mechanisms for leafhopper injury in dry beans, (Galwey and Evans, 1982; Kornegay and Cardona 1990; Kornegay and Temple, 1986; Kornegay et al., 1986; Schaafsma et al., 1998; van Schoonhoven et al., 1985). Antixenosis was observed in some resistant accessions at CIAT; however, this mechanism of resistance may be related to low yield and plant biomass (Kornegay and Cardona, 1990). The injury caused by E. kraemeri in the tropics is greater than injury caused by E. fabae in the temperate zone. This finding is likely related to the greater number of generations of the insect produced per year in the tropics. In addition to 'Sierra' and 'Tacarigua', resistance to leafhopper ( $E$. fabae and E. kraemeri) injury has been reported in dry beans 'Wells Red Kidney', 'Refugee' and U.S. 'Refugee No. 5' (Beyer, 1922; CIAT, 1975; Gates, 1945).

The low narrow-sense heritability estimates obtained for both crosses in this study is due to the large environmental effect on the expression of the PLH injury. Errors in rating due to difficulties in distinguishing small differences for PLH injury among the $\mathrm{F}_{2}$ genotypes in the intermediate classes also may contribute to low heritability estimates. Earlier studies also reported low correlation coefficients between
Sierra x Starlight

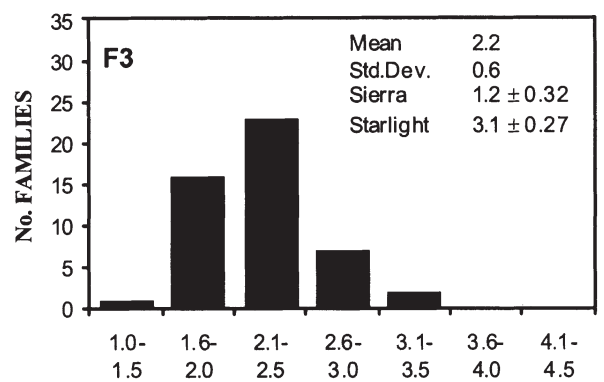

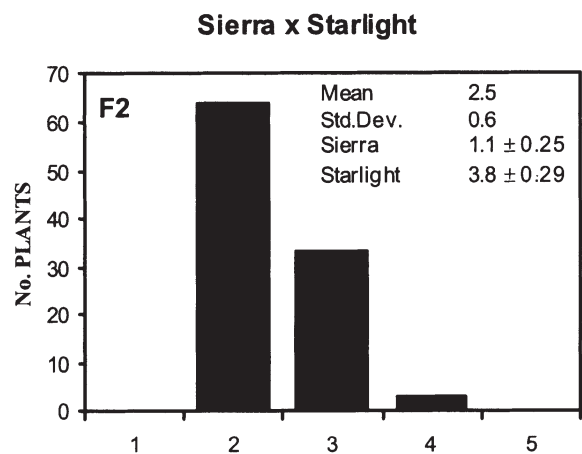

damage scores due to E. kraemeri in $\mathrm{F}_{2}$ plants and their $\mathrm{F}_{3}$ families although heritability was not estimated (Galwey and Evans, 1982). These authors (Galway and Evans, 1982), attributed among genotypes and to difficulties in rating PLH injury in individual plants. The significant genotype $\times$ environment $(P>\mathrm{F} 0.001)$ interaction for $\mathrm{F}_{3}$ families observed in both crosses in the current study may be a reason for the low $\mathrm{h}^{2}$ estimates.

Uniformity of insect infestation and PLH feeding and control of other factors causing similar plant symptoms (e.g., herbicide injury symptoms) as PLH feeding may help to secure more reliable results (Galwey and Evans, 1982). Those factors are difficult to control in experiments using $\mathrm{F}_{2}$ plants since there is no replication of the genotypes. Although it may be difficult to obtain good precision for $\mathrm{PLH}$ injury in the intermediate segregating rating classes of $\mathrm{F}_{2}$ plants, resulting in some genotypes incorrectly classified, the studies are still valuable.

The heritability estimates are useful in determining the amount of selection pressure to apply to get successful results when working on this trait. A high selection pressure is recommended when the heritability estimates are low in value. The development of recombinant inbred lines (RIL) from these crosses might be more useful than the $\mathrm{F}_{3}$ families from $\mathrm{F}_{2}$ in estimating heritability because it would permit the testing of large numbers of families in more replications and multiple locatheir results to the limited genetic variability
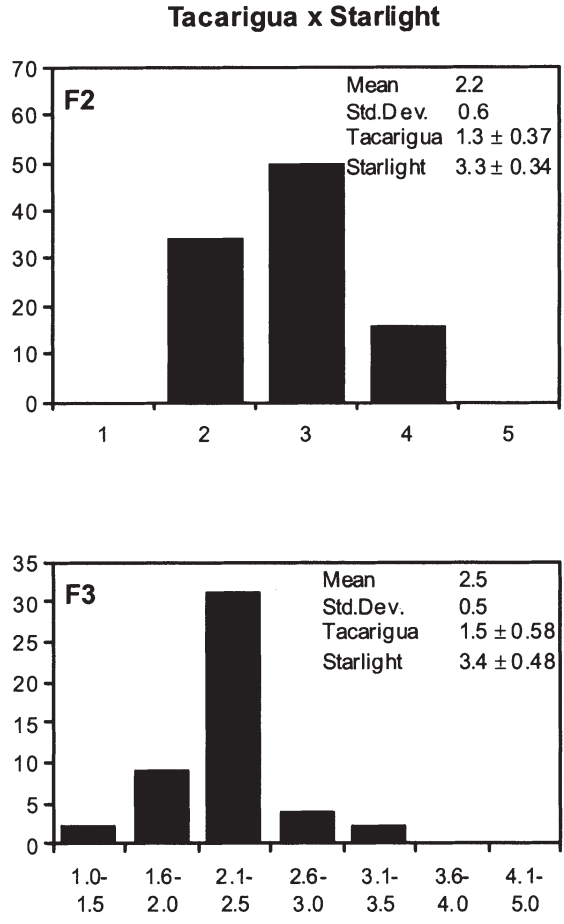

\section{INJURY RATINGS}

Fig. 1. Leafhopper injury rating distributions for $F_{2}$ individuals (1999) and $F_{3}$ random families (2000) for crosses pinto 'Sierra' (resistant) $\mathrm{x}$ great northern 'Starlight' (susceptible), and 'Tacarigua' (resistant) $\mathrm{x}$ great northern 'Starlight' (susceptible). $\mathrm{F}_{2}$ bean plants and $\mathrm{F}_{3}$ families grown at North Platte, Nebr. (rating scale: $1=$ no apparent injury, $5=$ severe injury). 
tions. This is particularly important since the incidence of PLH injury should be evaluated under the different conditions. Homozygous and homogeneous RIL planted in replicated tests over different environments would permit more precise evaluations of the response of the dry bean lines for PLH injury.

The heritability estimates from these studies used in conjunction with the availability of molecular markers linked to genes for PLH resistance could be useful for marker assisted selection (MAS) and gene pyramiding procedures. Application of those techniques would assist in combining resistance genes into individual cultivars to get a long lasting type of resistance especially when the trait has low heritability estimates.

Additional studies, including the screening of more lines/cultivars of dry beans, could result in increased resistance of dry beans to leafhopper injury. It would result in an economic savings by a reduction in the application of insecticides to control the potato leafhopper.

\section{Literature Cited}

Beyer, A.H. 1922. The bean-leafhopper and hopperburn with methods of control. Fla. Agr. Expt. Sta. Bul. No. 164.

Centro Internacional de Agricultura Tropical(CIAT).
1986. Stages of development of the common bean plant; study guide to be used as a supplement to the audiotutorial unit on the same topic. Scientific content: Fernando Fernández; Paul Gepts, and Marceliano López. English production: Oscar Arregocés, Rigoberto Hidalgo, and Adriana Correa. p. 32. Cali, Colombia. CIAT.

Centro Internacional de Agricultura Tropical (CIAT). 1980. Bean production problems in the tropics, $p$. 726. In: H.F. Schwartz and M.A. Pastor-Corrales (eds.). CIAT, Cali, Colombia.

Centro International de Agricultura Tropical (CIAT). 1975. Bean production systems: Entomology, p.125-130. In: Annual report 1974. CIAT, Cali, Colombia.

Galwey, N.W. and A.M. Evans. 1982. The inheritance of resistance to Empoasca kraemeri Ross and Moore in the common bean, Phaseolus vulgaris L. Euphytica 31:933-952.

Gates, D. 1945. Bean insect control. Nebr. Agr. Expt. Sta. Annu. Rpt. p. 58-61.

Gonzalez, A.L. and J.A. Wyman. 1991. Effect of varying potato leafhopper (Homoptera: Cicadellidae) population densities on snap bean yield. J. Econ. Entomol. 84:644-649.

Kornegay, J.L. and C. Cardona. 1990. Development of an appropriate breeding scheme for tolerance to Empoasca kraemeri in common bean. Euphytica 47:223-231.

Kornegay, J.L., C. Cardona, and A. van Schoonhoven. 1986. The mechanisms of resistance in common beans to the leafhopper Empoasca kraemeri. Entomol. Expt. Appl. 40:273-279.
Kornegay, J.L. and S.R. Temple. 1986. Inheritance and combining ability of leafhopper defense mechanisms in common bean. Crop Sci. 26:1153-1158.

Lindgren, D.T. and D.P. Coyne. 1995. Injury and yield of leafhopper-infested dry beans. J. Amer. Soc. Hort. Sci. 120:839-842.

Murray, J., A. Wylde, K.P. Pauls, T. Michaels, and A. Schaafsma. 2000. Detection of genetic loci for resistance to potatoleafhopper (Empoascafabae) in the common bean (Phaseolus vulgaris). Ann. Rept. Bean Improv. Coop. 43:27-28.

SAS Institute Inc. 1997. Selected SAS documentation for biometry 902: Advanced experimental design. SAS Inst., Cary, N.C.

Schaafsma, A.W., C. Cardona, J.L. Kornegay, A.M. Wylde, and T.E. Michaels. 1998. Resistance of common bean lines to the potato leafhopper (Homoptera: Cicadellidae). J. Econ. Entomol. 91:981-986.

Singh, S.P. 1999. Common bean improvement in the twenty-first century. In: Shree P. Singh (ed.). Kluwer Academic Publ., Dordrecht.

Smith, J.D. and M.L. Kinman. 1965. The use of parent-offspring regression as an estimator of heritability. Crop Sci. 5:595-596.

van Schoonhoven A., G.J. Hallman, and S.R. Temple. 1985. Breeding for resistance to Empoasca kraemeri Ross and Moore in Phaseolus vulgaris L. In: L.R. Nault and J.G. Rodriguez (eds.). The leafhoppers and planthoppers. Wiley, New York. 